\title{
In vitro production of gases with mixtures of Hyparrhenia rufa (Nees) and Leucaena leucocephala (Lam) de Wit
}

\author{
Ley de Coss, Alejandro ${ }^{1}$; Guerra-Medina, Candido E. ${ }^{* 2}$; Pérez-Luna, Esaú de Jesús; Avendaño-Arrazate, Carlos H. ${ }^{2}$; \\ Reyes-Gutiérrez, José A. ${ }^{3}$ \\ ${ }^{1}$ Cuerpo Académico en Desarrollo Agropecuario Sustentable, Facultad de Ciencias Agronómicas Campus V, \\ UNACH, Villaflores, Chiapas, México. \\ ${ }^{2}$ Campo Experimental Rosario Izapa; CIRPAS-INIFAP, Tuxtla Chico, Chiapas, México. \\ ${ }^{3}$ Grupo de Investigación en Nutrición Animal, Centro Universitario del Sur, Universidad de Guadalajara, \\ Ciudad Guzmán, Jalisco, México. \\ *Corresponding author: eguerranutricion@gmail.com
}

Citation: Ley de Coss, A., Guerra-Medina, C. E., Pérez-Luna, E. de J., Avendaño-Arrazate, C. H., \& Reyes-Gutiérrez, J. A. (2021). In vitro production of gases with mixtures of Hyparrhenia rufa (Nees) and Leucaena leucocephala (Lam) de Wit. Agro Productividad, 14(7).https:// doi.org/10.32854/agrop.v13i11.1876

Editor in Chief: Dr. Jorge Cadena Iñiguez

Estimated publication date: August 202

This work is licensed under a Creative Commons Attribution-Non-Commercial 4.0 International license.

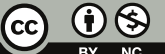

\begin{abstract}
Objective: To evaluate total in vitro gas and methane $\left(\mathrm{CH}_{4}\right)$ production in different mixtures of Hyparrhenia ruffa $(\mathrm{Hr})$ and Leucaena leucocephala $(\mathrm{Ll})$.

Design/methodology/approach: In airtight biodigesters with $200 \mathrm{~mL}$ of culture medium, $20 \mathrm{~g}$ of the following treatments were incubated by triplicate: T1: $100 \% \mathrm{Hr}$, T2: $80 \% \mathrm{Hr}+20 \% \mathrm{Ll}$, T3: $60 \% \mathrm{Hr}+40 \% \mathrm{Ll}$, T4: $40 \% \mathrm{Hr}+60 \% \mathrm{Ll}$; these were inoculated with $20 \mathrm{~mL}$ of fresh rumen fluid and incubated at $38 \pm 0.5^{\circ} \mathrm{C}$ for 24, 48, 72 and $96 \mathrm{~h}$. The total gas and $\mathrm{CH}_{4}$ production were assessed; the data were analyzed in a completely randomized design.

Results: The addition of $20 \%, 40 \%$ and $60 \% \mathrm{Ll}$ in mixture with $\mathrm{Hr}$ decreased the neutral detergent fiber (NDF), acid detergent fiber (ADF), total gas and $\mathrm{CH}_{4}$ production, while the crude protein content increased.

Study limitations/implications: In vivo studies are required / by including amounts higher than 20\% Ll may improve energy utilization efficiency.

Findings/conclusions: Adding more than 20\% L. leucocephala in a mixture with $H$. ruffa decreases total gas and $\mathrm{CH}_{4}$ production.
\end{abstract}

Keywords: methane, ruminants, tropical grasses, forage shrubs.

\section{INTRODUCTION}

The digestive process of the food consumed by ruminants involves physical, microbiological and chemical processes. The fermentation of food in the rumen is carried out by microorganisms, including bacteria, protozoa and fungi; the products of fermentation are: energy in the form of adenine triphosphate (ATP), which is used by microorganisms to grow and reproduce, the process involves the synthesis of microbial mass that will be later digested in the abomasum and used by the ruminant as a true protein source; volatile fatty acids such as acetic, propionic and butyric are also produced, which will be used by the ruminant as a principal energy source. As secondary products of fermentation, 
carbon dioxide $\left(\mathrm{CO}_{2}\right)$, hydrogen $\left(\mathrm{H}_{2}\right)$ and $\mathrm{CH}_{4}$ are produced, these are synthesized from the fermentation of structural carbohydrates products by rumen methanogenic archaea such as Methanobrevibacter ruminantium, Methanobacterium formicicum, Methanomicrobium mobile (Cobos et al., 2018).

The CH4 production is necessary for the oxidation of nicotin adenine dinucleotide (NAD), it is a step in the process for obtaining the energy contained in the neutral detergent fiber (NDF) and other nutrients in the diet, due that this process reduces the accumulation of $\mathrm{H}_{2}$, it regulates $\mathrm{pH}$ and reduces ruminal pressure (Sharp et al., 1998; Ley de Coss et al., 2018) to maintain ruminal stability (Galindo et al., 2010). In a second process, with the manure fermentation, nitrous oxide $\left(\mathrm{N}_{2} \mathrm{O}\right)$ is produced, a gas with 310 times the potential of heat retaining than $\mathrm{CO}_{2}$ (Ellis et al., 2012).

Methane emissions from bovine enteric fermentation account for about 39\% of the greenhouse gases (GHG) produced by the livestock sector (Arbre et al., 2016), it is necessary to reverse the negative trends of extensive livestock farming, where the increase of $\mathrm{CO}_{2}$ was of $70 \%$ and $40 \%$ for $\mathrm{CH}_{4}$ during the 1970 to 2004 period (IPCG, 2016). To achieve this, it is required to design and evaluate methodologies to accurately calculate the energy flow and its relationship with GHG emissions in livestock activity (De-Vries and de-Boer, 2010).

In the southern and southeastern regions of Mexico, the ruminants' diet is based on forage grasses and shrubs; the former has a higher NDF, acid detergent fiber (ADF) and lower protein content, which favors higher $\mathrm{CO}_{2}, \mathrm{H}_{2}$ and $\mathrm{CH}_{4}$ production. Methane production in tropical regions is of $20 \mathrm{~L} \mathrm{~kg}^{-1}$ of fermented dry matter (Piñeiro et al., 2017), with energy losses in the form of $\mathrm{CH}_{4}$ of up to $18 \%$, so that, by using feeding strategies that allow greater efficiency in energy utilization, emissions of this gas could be reduced and cattle productivity improved (Vanlierde et al., 2016).

The rate of $\mathrm{CH}_{4}$ emissions from ruminal fermentation is directly related to the intake, nutrient content, physical and chemical characteristics and diet digestibility. Therefore, a strategy to reduce enteric methane production is through feeding management that allows changes in the ruminal fermentation pattern (Piñeiro et al., 2017). The inclusion of forage trees and shrubs in the feeding of ruminants has improved NDF degradation, due to the higher crude protein contribution. When $20 \%$ of L. leucocephala was included in the diet, $\mathrm{CH}_{4}$ production was reduced by $26 \%$ (Piñeiro et al., 2015). Reduction in $\mathrm{CH}_{4}$ emission was also observed with the shrubs as L. leucocephala, Sapindus saponaria, Calliandra calothyrsus, Pithecellobium dulce, Heliocarpus velutinus and Guazuma ulmifolia, when supplied with low quality pasture or with Megathyrsus maximus (Gaviria et al., 2015; Lopez et al., 2016). Based on the above, the objective was to assess the total gases and $\mathrm{CH}_{4}$ production, when combined with Hyparrhenia ruffa grass and Leucaena leucocephala in in vitro incubation.

\section{MATERIALS AND METHODS}

Location of the study. The research took place from May 1 to June 30, 2019, in the Jaulas Metabólicas area and the Laboratorio de Sanidad Agropecuaria at the Facultad de Ciencias Agronómicas, Campus V of the Universidad Autónoma de Chiapas located at the Centro Universitario de Transferencia de Tecnología (University Center for Technology Transfer, CUTT) "San Ramón”, Carretera al ejido 16 de septiembre km 2.5 in Villaflores, 
Chiapas, Mexico (16 27' 59" N and 93 28' 43" W). From September 2 to 16, 2019, the analyses were performed at the Laboratorio de Nutrición Animal of the Programa en Ganadería from the Colegio de Postgraduados, Campus Montecillos, México (19²7' 39.24" $\mathrm{N}$ and $98^{\circ} 54^{\prime} 29.19^{\prime \prime} \mathrm{W}$ ).

Chemical analysis of samples. The mixtures of $H$. ruffa and L. leucocephala were analyzed for total dry matter (TDM), crude protein (CP) following the Kjeldahl method, ethereal extract (EE) via the Soxhlet method, crude fiber $(\mathrm{CF})$ by the Weende method, ash $(\mathrm{C})$ and organic matter $(\mathrm{OM})$ by difference, all using the techniques described by the AOAC (2012). The fiber fractions (NDF and FDA) determination was performed with alpha-amylase without ash correction as specified by Van Soest et al. (1991).

Growth medium and treatments. Rumen liquid (RL) from a $525 \mathrm{~kg}$ live weight male Brown Swiss bovine was used, the RL was extracted with an esophageal tube with a vacuum pump. The bovine received a diet with $85 \%$ Hyparrhenia rufa and $15 \%$ of a concentrated feed, containing 2.7 Mcal of ME and 14\% crude protein (CP), the culture medium used to determine total gas (TG) production, $\mathrm{CO}_{2}$ and $\mathrm{CH}_{4}$ ratios and DM degradation (Table 1), was prepared in sterile conditions and low $\mathrm{CO}_{2}$ flow.

The evaluated treatments were: T1: 100\% Hyparrhenia rufa $(\mathrm{Hr}), \mathrm{T} 2: 80 \% \mathrm{Hr}+20 \% \mathrm{~L}$. leucocephala $(\mathrm{Ll}), \mathrm{T} 3: 60 \% \mathrm{Hr}+40 \% \mathrm{Ll}, \mathrm{T} 4: 40 \% \mathrm{Hr}+60 \% \mathrm{Ll}$.

Table 1. Culture medium for in vitro fermentation of dry matter of Hyparrhenia rufa and Leucaena leucocephala mixtures.

\begin{tabular}{l|c}
\multicolumn{1}{c|}{ Compound } & $\begin{array}{c}\text { Quantity }(\mathbf{m L}) \text { for } \mathbf{1 0 0} \\
\text { mL of medium }\end{array}$ \\
\hline Destilled water & 52.9 \\
\hline Clarified rumen fluid $^{(1)}$ & 30.0 \\
\hline Mineral solution I $^{(2)}$ & 5.0 \\
\hline Mineral solution II $^{(3)}$ & 5.0 \\
\hline${\text { Sodium carbonate }\left(\mathrm{Na}_{2} \mathrm{CO}_{3}\right), 8 \%{ }^{(4)}}^{(5)}$ & 5.0 \\
\hline Sulfide-cysteine solution $^{(5)}$ & 2.0 \\
\hline Resazurin solution, $0.1 \%{ }^{(6)}$ & 0.1 \\
\hline
\end{tabular}

(1) Clarified rumen fluid filtrated and centrifugated at $17,664 \mathrm{~g}$ for 15 min and sterilized $20 \mathrm{~min}$ at $21^{\circ} \mathrm{C}$ a 15 psi. (2) Contains (in $1000 \mathrm{~mL}$ ) $6 \mathrm{~g}$ $\mathrm{K}_{2} \mathrm{HPO}_{4}$. (3) Contains (in $\left.1000 \mathrm{~mL} \mathrm{H}_{2} \mathrm{O}\right), 6 \mathrm{~g} \mathrm{KH}{ }_{2} \mathrm{PO}_{4}, 6 \mathrm{~g}\left(\mathrm{NH}_{4}\right)_{2} \mathrm{SO}_{4}$, $12 \mathrm{~g} \mathrm{NaCl}, 2.45 \mathrm{~g} \mathrm{MgSO}_{4}$ y $1.6 \mathrm{~g} \mathrm{CaCl}_{2} \cdot \mathrm{H}_{2} \mathrm{O}$. (4) $8 \mathrm{~g} \mathrm{Na}_{2} \mathrm{CO}_{3}$ in $100 \mathrm{~mL}$ $\mathrm{H}_{2} \mathrm{O}$ destilled. (5) $2.5 \mathrm{~g} \mathrm{~L}$-cysteine (in $\left.15 \mathrm{~mL} 2 \mathrm{~N} \mathrm{NaOH}\right)+2.5 \mathrm{~g} \mathrm{Na} 2 \mathrm{~S}$ $9 \mathrm{H}_{2} \mathrm{O}$ (in $100 \mathrm{~mL} \mathrm{H} \mathrm{H}_{2} \mathrm{O}$ ). (6) $0.1 \mathrm{~mL}$ resazurin in $100 \mathrm{~mL}$.

Production of total gases and $\mathbf{C H}_{4}$. The in vitro production of TG and $\mathrm{CH}_{4}$ was determined by triplicate with repetition throughout time using $2.0 \mathrm{~L}$ capacity biodigesters with a hermetic look, to which the following mixture was added in aseptic conditions and $\mathrm{CO}_{2}$ flow: $20 \mathrm{~g}$ of $\mathrm{DM}$ of each treatment plus $200 \mathrm{~mL}$ of culture medium (Table 1), each treatment was inoculated with $20 \mathrm{~mL}$ of fresh RL, which was filtered in cotton gauze and kept in a water bath at $38 \pm 0.5^{\circ} \mathrm{C}$ and $\mathrm{CO}_{2}$ flow. The initial total bacteria concentration was counted with the most probable number (MPN) technique with $1.30 \times 10^{8} \mathrm{CFU} \mathrm{mL}^{-1}$ 
at $\mathrm{pH}$ 6.72. The inoculated treatments were incubated for 24, 48, 72 and $96 \mathrm{~h}$ in a water bath at $38 \pm 0.5^{\circ} \mathrm{C}$. At the end of the incubation period, the TG pressure was measured with a manometer adapted to the equipment. Afterward, the amount of produced TG in the system was assessed using the liquid displacement technique through a trap with Mariotte flasks.

The displaced water was collected in a graduated cylinder and the amount of gas produced per gram of fermented DM ( $\mathrm{mL}$ of gas $\mathrm{g}^{-1}$ of MSf) was determined. In a second run and under the same culture conditions and temperature, a $2 \mathrm{~N} \mathrm{NaOH}$ solution $(20 \mathrm{~g}$ $\left.\mathrm{L}^{-1}\right) \mathrm{pH} 13.57$ was added to the Mariotte flask traps; the $\mathrm{NaOH}$ solution upon reacting with $\mathrm{CO}_{2}$ formed $\mathrm{Na}_{2} \mathrm{CO}_{3}$ and the released gases were a mixture of $\mathrm{CH}_{4}, \mathrm{H}_{2}, \mathrm{~N}_{2}$ and $\mathrm{H}_{2} \mathrm{~S}$ according to the technique described by Ley de Coss et al. (2018); the $\mathrm{CO}_{2}$ trap was coupled to the biodigester using a Taygon hose ( $5 \mathrm{~mm}$ internal $35 \mathrm{~cm}$ length) to which a $31.8 \mathrm{~mm} 20 \mathrm{G}$ hypodermic needle was attached. In all TG production evaluations, the result was corrected by difference to the gas production of the blank samples $(200 \mathrm{~mL}$ of culture medium plus $20 \mathrm{~mL}$ of $\mathrm{RL}$ ), as well as with the $\mathrm{CH}_{4}$ concentration measurements using the gas trap technique with saline solution.

Statistical analysis. The experimental design was in a completely randomized design, total gas and $\mathrm{CH}_{4}$ production data were analyzed with the PROC GLM procedure of the Statistical Analysis System (SAS) (SAS, 2011) and the means of the treatments were compared with Tukey's test $(\mathrm{P} \leq 0.05)$.

\section{RESULTS AND DISGUSSION}

\section{Chemical composition of the diets}

Table 2 shows the chemical composition of the H. ruffa and L. leucocephala evaluated mixtures. By increasing the L. leucocephala proportion from $0.0 \%$ to $60 \%$ of the mixture, the NDF content decreased from $55.7 \%$ to $38.2 \%$; FDA from $28.7 \%$ to $18.4 \%$; while the CP content increased from $8.3 \%$ to $18.1 \%$ and the ethereal extract from $0.8 \%$ to $2.4 \%$. The increase in CP content and reduction of NDF and FDA could have an impact on the production of TG and $\mathrm{CH}_{4}$, during in vitro fermentation (Piñeiro et al., 2017). One of the factors that modify the fermentation pattern and products is the amount of fermentable NDF; in this study, the $100 \%$ H. ruffa fermentation, showed a higher production of total gases (Table 3). Grasses from tropical regions such as $H$. ruffa have a higher NDF amount than shrubs, which generates fermentation patterns with higher $\mathrm{CH}_{4}$ production (Archimède et al., 2011).

\section{Total gas production}

Table 3 shows that increasing the L. leucocephala content in the mixture from $0.0 \%$ to $20 \%$ decreased the TG production at 24 and $96 \mathrm{~h}$ of incubation $(\mathrm{P}<0.05)$, at 48 and $72 \mathrm{~h}$ there was no difference between both treatments $(\mathrm{P}>0.05)$. When the $L$. leucocephala proportion increased to $40 \%$, TG production was lower at all incubation hours $(\mathrm{P}<0.05)$ compared to the treatment without L. leucocephala, and there was also a difference $(\mathrm{P}<0.05)$ compared to the treatment where $20 \%$ L. leucocephala was included at all incubation hours. 
Table 2. Chemical composition of Hyparrhenia ruffa and Leucaena leucocephala mixtures (g per $100 \mathrm{~g}$ of dry matter).

\begin{tabular}{l|r|r|r|r}
\hline & \multicolumn{4}{|c}{ Proportion of H. ruffa: L. leucocephala } \\
\hline Nutrient (\%) & \multicolumn{1}{|c|}{100} & $80: 20$ & $60: 40$ & $40: 60$ \\
\hline Dry material & 93.4 & 92.8 & 92.1 & 91.5 \\
\hline Ashes & 9.0 & 8.9 & 8.8 & 8.7 \\
\hline Raw Fiber & 28.8 & 26.7 & 24.7 & 22.6 \\
\hline NDF & 55.7 & 49.9 & 44.0 & 38.2 \\
\hline ADF & 28.7 & 25.3 & 21.8 & 18.4 \\
\hline Raw protein $(\mathrm{N} \times 6.25)$ & 8.3 & 11.5 & 14.8 & 18.1 \\
\hline Ethereal extract & 0.8 & 1.3 & 1.9 & 2.4 \\
\hline NFE & 53.3 & 52.0 & 50.7 & 49.4 \\
\hline
\end{tabular}

NDF, Neutral detergent fiber; ADF, Acid detergent fiber; N, Nitrógen; NFE, Nitrogen free extract.

Table 3. Cumulative in vitro total gas production ( $\mathrm{mL}$ of gas per $20 \mathrm{~g}$ of fermented DM).

\begin{tabular}{c|c|c|c|c}
\hline \multirow{2}{*}{$\begin{array}{c}\text { Treatments } \\
\text { Hyparrhenia ruffa: Leucaena leucocephala }\end{array}$} & \multicolumn{4}{|c}{ Time (h) } \\
\cline { 2 - 5 } & $\mathbf{2 4}$ & $\mathbf{4 8}$ & $\mathbf{7 2}$ & $\mathbf{9 6}$ \\
\hline 100 & $150.03^{\mathrm{a}}$ & $248.82^{\mathrm{a}}$ & $357.75^{\mathrm{a}}$ & $605.47^{\mathrm{a}}$ \\
\hline $80: 20$ & $99.60^{\mathrm{b}}$ & $245.69^{\mathrm{a}}$ & $353.37^{\mathrm{a}}$ & $480.89^{\mathrm{b}}$ \\
\hline $60: 40$ & $91.77^{\mathrm{c}}$ & $143.91^{\mathrm{b}}$ & $263.26^{\mathrm{b}}$ & $348.04^{\mathrm{c}}$ \\
\hline $40: 60$ & $89.93^{\mathrm{c}}$ & $123.78^{\mathrm{b}}$ & $234.72^{\mathrm{b}}$ & $300.75^{\mathrm{c}}$ \\
\hline SEM & 2.84 & 9.17 & 26.48 & 22.85 \\
\hline DMS & 7.43 & 23.99 & 69.24 & 42.08 \\
\hline
\end{tabular}

SEM: Standart error of the mean; MSD: Minimum significant difference. ${ }^{\mathrm{a}, \mathrm{b}, \mathrm{c}}$ Means with different letters within the same column differ from each otther, according to Tukey test $(\mathrm{P}<0.05)$.

When the L. leucocephala proportion of the mixture increased to $60 \%$, there was no difference in total gas production $(\mathrm{P}>0.05)$ compared to the treatment with $40 \%$ of $L$. leucocephala, indicating that with higher than $40 \%$ levels in the mixture, TG production did not increase. In all assessed treatments, the highest TG production was recorded between the 48th and 72nd hours of incubation.

When analyzing the proportion increase in the TG at $48 \mathrm{~h}$, when the proportion of $L$. leucocephala increased from 0 to $20 \%$, the production decreased by $1.25 \%$, while when the proportion increased from $20 \%$ to $40 \%$, the decrease was $41.42 \%$, and when the proportion of L. leucocephala increased from $40 \%$ to $60 \%$, the total gas production decreased by $13.98 \%$.

In this research, the result indicates that the greatest effect in the TG decrease production is obtained when $40 \%$ of $L$. leucocephala is included. This effect could be related to the NDF and CP content of the different mixtures (Table 2), since, as the proportion of $L$. leucocephala in the mixture increases, the NDF content decreases and the CP content increases, due to a lower proportion of cell walls. With that, the fermentation pattern changes, the amount of potentially fermentable cell walls decreases, and consequently the amount and proportion of volatile fatty acids decreases. This decreases the proportion of acetate, $\mathrm{H}_{2}, \mathrm{CO}_{2}$ and increases the proportion of propionate. It is reported that in diets 
with L. leucocephala containing 14\% of CP, methane production is reduced (Lovett et al., 2004), and when NDF and FDA levels are lower, there is lower total gases production (Waghorn and Hegarty, 2011).

\section{$\mathrm{CH}_{4}$ production}

A similar trend was observed in the $\mathrm{CH}_{4}$ production to that obtained in TG production. The highest amount of $\mathrm{CH}_{4}$ produced was in the treatment with $100 \%$ H. ruffa at 24 and $96 \mathrm{~h}$ of incubation $(\mathrm{P}<0.05)$. At $24 \mathrm{~h}$ of incubation, when the proportion of L. leucocephala increased from $0.0 \%$ to $20 \%, \mathrm{CH}_{4}$ production decreased $(\mathrm{P}<0.05)$, and the same response was observed when the L. leucocephala content was of 40 and $60 \%$. At 48 and $72 \mathrm{~h}$, there was a difference when 40 and $60 \%$ of $L$. leucocephala were included. The results obtained in this research show that increasing L. leucocephala content in the mixture decreases $\mathrm{CH}_{4}$ production. Higher NDF and FDA content has been related to higher $\mathrm{CH}_{4}$ production (Lopez et al., 2016; Vélez et al., 2018). When there is lower availability of digestible nutrients and higher cell wall content (NDF and FDA), $\mathrm{CH}_{4}$ production is favored, while high levels of fast-fermenting carbohydrates and CP reduce $\mathrm{CH}_{4}$ production (Owens et al., 1998).

Table 4. Cumulative $\mathrm{CH}_{4}$ production in in vitro incubations ( $\mathrm{mL}$ of gas per $20 \mathrm{~g}$ of fermented DM).

\begin{tabular}{c|c|c|c|c}
\hline \multirow{2}{*}{$\begin{array}{c}\text { Treatments } \\
\text { Hyparrhenia ruffa: Leucaena leucocephala }\end{array}$} & \multicolumn{4}{|c}{ Time (h) } \\
\cline { 2 - 5 } & $\mathbf{2 4}$ & $\mathbf{4 8}$ & $\mathbf{7 2}$ & $\mathbf{9 6}$ \\
\hline 100 & $111.97^{\mathrm{a}}$ & $176.19^{\mathrm{a}}$ & $272.45^{\mathrm{a}}$ & $451.81^{\mathrm{a}}$ \\
\hline $80: 20$ & $66.43^{\mathrm{b}}$ & $173.09^{\mathrm{a}}$ & $253.46^{\mathrm{a}}$ & $354.99^{\mathrm{b}}$ \\
\hline $60: 40$ & $47.89^{\mathrm{b}}$ & $74.68^{\mathrm{b}}$ & $125.21^{\mathrm{b}}$ & $167.47^{\mathrm{c}}$ \\
\hline $40: 60$ & $40.59^{\mathrm{b}}$ & $57.58^{\mathrm{b}}$ & $114.22^{\mathrm{b}}$ & $148.15^{\mathrm{c}}$ \\
\hline SEM & 10.41 & 16.25 & 14.34 & 21.43 \\
\hline MSD & 27.22 & 42.47 & 37.49 & 40.32 \\
\hline SEM: Standart error of the mean; MSD: Minimum significant difference. ${ }^{\mathrm{a}, \mathrm{b}, \mathrm{c}}$ Means with different
\end{tabular}

letters within the same column differ from each otther, according to Tukey test $(\mathrm{P}<0.05)$.

\section{CONGLUSIONS}

By including higher than $20 \%$ levels of L. leucocephala in mixtures with $H$. ruffa grass in in vitro incubations, total gas production and $\mathrm{CH}_{4}$ production decrease, due to the change in the fermentation pattern caused by decreasing the NDF and FDA content of the mixture, and at the same time increasing the crude protein content.

\section{REFERENCES}

AOAC (2012). Official Methods of Analysis of the Association of Official Analytical. AOAC (Association of Official Analytical Chemists). 2012. Official Methods of Analysis (19th Edition). Association of Official Analytical Chemists. Gaithersburg, Mary Land, USA. Chapter 4: 1-44.

Arbre, M., Rochette, Y., Guyader,J., Lascoux, C., Gómez, L. M., Eugène, M., Martin, C. (2016). Repeatability of enteric methane determinations from cattle using either the SF6 tracer technique or the Green Feed system. Animal Production Science. 56 (3): 238-243. Doi: 10.1071/ AN15512

Archimède, H., Eugène, M., Marie, M. C., Boval, M., Martin, C., Morgavi, D. P., and Doreau, M. (2011). Comparison of methane production between C3 and C4 grasses and Legumes. Animal Feed Science and Technology. 166(167): 59-64. Doi: 10.1016/j.anifeedsci.2011.04.003

Cobos, M. A., Curzaynz, K. R., Rivas, M. I., Santillán, E. A. and Bárcena, R. (2018). In vitro Effect of diets for growing lambs supplemented with dried distiller grains on rumen fermentation and gas emissions. Agrociencia. 52(2): 203-215. 
De-Vries, M. and de Boer, I. J. M. (2010). Comparing environmental impacts for livestock products: A review of life cycle assessments. Livestock Science. 128(1-3): 1-11. Doi: 10.1016/j.livsci.2009.11.007

Ellis, J. L., Dijkstra, J., France, J., Parson, A. J., Edwards, G. R., Rasmussen, S. and Bannink, A. (2012). Effect of high-sugar grasses on methane emissions simulated using a dynamic model. Journal of Dairy Science. 95(1): 272-285. Doi: 10.3168/jds.2011-4385

Galindo, J., Marrero, Y., González, N., Sosa, A., Miranda, A. L., Aldana, A. I. y Noda, A. (2010). Efecto de preparados con levaduras Saccharomyces cerevisiae y LEVICA-25 viables en los metanógenos y metanogénesis ruminal in vitro. Revista Cubana de Ciencia Agrícolas. 44(3): 273279.

Gaviria, X., Naranjo, J. F. y Barahona, R. (2015). Cinética de fermentación in vitro de Leucaena leucocephala y Megathyrsus maximus y sus mezclas, con o sin suplementación energética. Pastos y Forrajes. 38 (1): 55-63.

IPCG, Intergovernmental Panel on Climate Change (2016). Report of IPCG Scoping Meeting for a Methodology Report(s) to refine the 2006 IPCG Guidelines for National Greenhouse Gas Inventories. In: S. Ngarize, A. Kranjc, J. Baasansuren y P. Shermanau (Eds), Report of the IPCC Scoping Meeting (pp.25-27). Japan: Pub. IGES.

Ley de Coss, A., Guerra, M. E., Montañez, D. O., Guevara, F., Pinto, R. R. y Reyes, J. (2018). In vitro production of gas methane by tropical grasses. Revista MVZ Córdoba. 23: 6788-6798.

Lopez, D., Vázquez, A. J. F., Lopez, V. N., Lee, R. H. A., Salem, A. Z. M., Borquez, G. J. L., Rojo, R. R. (2016). In vitro gas production of foliage from three browse tree species treated with different dose levels of exogenous fibrolytic enzymes. Journal of Animal Physiology and Animal Nutrition. 100: 920-928.

Lovett, D. K., Bortolozzo, A., Gonaghan, P., O’Kiely, P. O. and O’Mara, F. P. (2004). In vitro total and methane gas production as influenced by rate of nitrogen application, season of harvested perennial rye grass cultivar. Grass Forage Science. 59: $227-232$.

Owens, F. N., Secrist, D. S., Hill, W. J. and Gill, D. R. (1998). Acidosis in cattle: A review. Journal of Animal Science. $76: 275-286$.

Piñeiro, V. A. T., Canul, S. J. R., Alayon, G. J. A., Chay, C. A. J., Ayala, B. A. J., Solorio, S. F. J. and Ku, V. J. C. (2017). Energy utilization, nitrogen balance and microbial protein supply in cattle fed Pennisetum purpureum and condensed tannins. Journal of Animal Physiology and Animal Nutrition. 101: 159-169.

Piñeiro, V. A. T., Canul, S. J. R., Alayón, G. J. A., Chay, C. A. J., Ayala, B. A. J., Aguilar, P. C. F. and Ku, V. J. C. (2015). Potential of condensed tannins for the reduction of emissions of enteric methane and their effect on ruminant productivity. Archivos de Medicina Veterinaria. 47: 263-272.

SAS. Institute, Inc. (2011). Statistical Analysis System, SAS/STAT. Versión 9.3. User’s Guide: SAS Inst., Cary, NC. pp 177-178.

Sharp, R., Ziemer, C. J., Stern, M. D. and Stahl, D. A. (1998). Taxon-specific associations between protozoal and methanogen populations in the rumen and a model rumen system. FEMS Microbiology Ecology. 26: 71-78.

Vanlierde, A., Marie, L. V., Gengler, N., Dardenne, P., Froidmont, E., Soyeurt, H., Dehareng, F. (2016). Milk mid-infrared spectra enable prediction of lactation-stage-dependent methane emissions of dairy cattle within routine population-scale milk recording schemes. Animal Production Science. 56: 258-264.

Van Soest, P. J., Robertson, B., \& Lewis, B. A. (1991). Methods for dietary fiber, neutral detergent fiber and nonstarch polysaccharides in relation to animal nutrition. Symposium: carbohydrate methodology, metabolism, and nutritional implications in dairy cattle. Journal of Dairy Science. 74: 3583-3597.

Vélez, T. M., Campos, G. R., Sánchez, G. H. and Giraldo, L. A. (2018). Fermentation dynamics and methane production of diets based on Brachiaria humidicola with high inclusion levels of Enterolobium schomburgkii and Senna occidentalis in a Rusitec System. Tropical and Subtropical Agroecosystems. 21: 163-175.

Waghorn, G. C. and Hegarty, R. S. (2011). Lowering ruminant methane emissions through improved feed conversion efficiency. Animal Feed Science and Technology. 166-67: 291-301. 